\title{
Eru íslenskir verðbréfasjóðir með alpjóðlega fjárfestingarstefnu samkeppnishæfir við sambærilega erlenda sjóði?
}

\author{
Guðmundur Pálsson, Kári Sigurðsson og Sigurður G. Gíslason ${ }^{1}$
}

\begin{abstract}
Ágrip
Pessi grein fjallar um hvort íslenskir verðbréfasjóðir með alpjóðlega fjárfestingarstefnu séu samkeppnishæfir við sambærilega erlenda sjóði. Niðurstöður benda til pess að svo sé. Í fyrsta lagi skila íslensku sjóðirnir örlítið hærri meðalávöxtun en árangur sjóðanna er svipaður pegar búið er að leiðrétta fyrir áhættu. Íslensku sjóðirnir taka almennt meiri heildaráhættu en peir erlendu og skýrist sá munur eingöngu af kerfisbundinni áhættu. Í öðru lagi eru ekki vísbendingar um að íslensku sjóðunum sé lokað vegna lélegs árangurs líkt og pekkist í Bandaríkjunum. Ekki eru heldur afgerandi vísbendingar um að nöfnum íslensku sjóðanna sé breytt í kjölfar lélegs árangurs. Í priðja og síðasta lagi bera íslensku sjóðirnir lægri inn- og útgöngukostnað samanborið við pá erlendu en umsýslupóknun er svipuð.
\end{abstract}

\begin{abstract}
This paper is about whether Icelandic mutual funds with international investments strategies are competitive with comparable foreign funds. The main results indicate that so is the case. Firstly, the Icelandic funds have a slightly higher average return but when returns have been adjusted for risk the performance is almost identical. The Icelandic funds take more risk than the foreign funds, which is explained totally by systematic risk. Secondly, there are no indications that Icelandic funds are closed or names are changed because of bad performance. Finally, the Icelandic funds have lower front load and back end load compared to the foreign funds but the management fees are similar.
\end{abstract}

JEL-flokkun: G23

Lykilhugtök: Mutual funds, Performance measurement; verðbréfasjóðir, árangursmælingar.

1 Guðmundur Pálsson er fulltrúi í eignastýringadeild hjá Söfnunarsjóði lífeyrissréttinda. Kári Sigurðsson er lektor við Háskólann í Reykjavík og starfar við eignastýringu hjá Barclays Global Investors. Sigurður Guðjón Gíslason er sérfræðingur í eignastýringadeild Glitnis. Höfundar pakka verðbréfasjóðum Glitnis, Kauppings, Landsbanka og VSP fyrir að veita aðgang að gögnum fyrir rannsóknina. 


\section{Inngangur}

Undanfarin ár hafa eignir íslenskra lífeyrissjóða farið ört vaxandi og voru pær 135\% af vergri landsframleiðslu í lok janúar árið 2007. Petta hlutfall er með pví hæsta sem pekkist í heiminum. Hluti af eignum pessara sjóða er ávaxtaður í gegnum verðbréfasjóði sem eru reknir af íslenskum sjóðastýringarfyrirtækjum. Pessir verðbréfasjóðir komu fyrst fram á sjónarsviðið um miðjan níunda áratuginn og síðan pá hefur peim fjölgað umtalsvert og fjárfestingarflóran orðið fjölbreyttari. Um pað bil tíu árum eftir að fyrstu sjóðirnir litu dagsins ljós byrjuðu sjóðastýringarfyrirtækin að bjóða upp á sjóði með alpjóðlega fjárfestingarstefnu. Fyrstu sjóðirnir af pessari tegund voru stofnaðir á seinni hluta tíunda áratugarins og í lok árs 2006 voru 15 slíkir sjóðir starfandi. Prátt fyrir töluvert framboð af sjóðum með erlenda fjárfestingarstefnu skipa peir ekki stóran sess ef miðað er við markaðsverðmæti. Einungis $8 \%$ af heildareignum íslenskra verðbréfasjóða (rúmir 33 milljarðar) eru alpjóðleg verðbréf sem samanstanda nær einungis af erlendum hlutabréfum (sjá mynd 1).

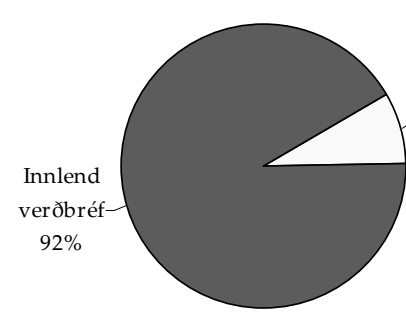

Erlend verðbréf $8 \%$ (1)

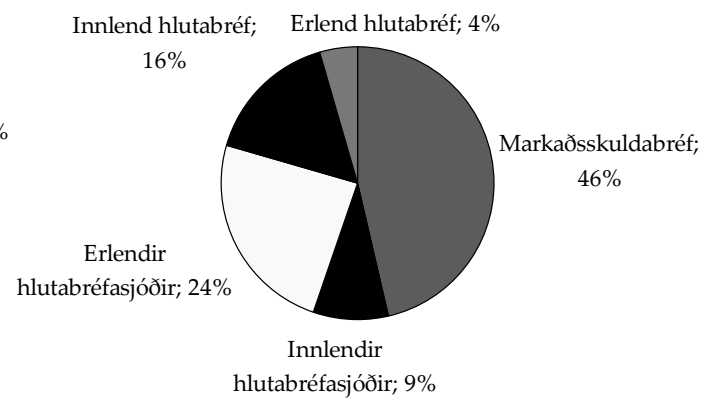

Mynd 1. Hlutfallsleg skipting á verðbréfaeign íslenskra verðbréfasjóða (til vinstri)² og íslenskra lífeyrissjóða (til hægri) ${ }^{3}$ í desember 2006.

Meðal stærstu viðskiptavina íslenskra sjóðastýringarfyrirtækja eru innlendir lífeyrissjóðir og par af leiðandi ættu verðbréfasjóðirnir að endurspegla fjárfestingar peirra. ${ }^{4}$ petta er hins vegar ekki raunin á Íslandi pegar kemur að erlendum fjárfestingum. Á meðan íslenskir verðbréfasjóðir fjárfesta áfram mestmegnis í íslenskum verðbréfum hafa lífeyrissjóðir fjárfest erlendis í auknum mæli, bæði beint og í gegnum erlenda hlutabréfasjóði. Eign íslenskra lífeyrissjóða í erlendum hlutabréfasjóðum í árslok 2006 nam um $24 \%$ af heildarverðbréfaeign eða nálægt 315 milljörðum (sjá mynd 1). Alpjóðleg verðbréfaeign íslensku verðbréfasjóðanna var hins vegar einungis um $8 \%$ af heildareignum eða 33 milljarðar í árslok 2006 og pví er ljóst að íslenskir lífeyrissjóðir fjárfesta fyrst og fremst í sjóðum sem eru reknir af erlendum sjóðastýringarfyrirtækjum. Petta gerir pað að verkum að íslensku sjóðastýringarfyrirtækin missa bæði af verðmætri pekkingu við að fjárfesta á

\footnotetext{
${ }^{2}$ Heimild: Seðlabanki Íslands.

${ }^{3}$ Heimild: Seðlabanki Íslands og heimasíða Landssamtaka lífeyrissjóða: http://www.ll.is.

${ }_{4}^{4}$ Pess ber að geta að flestir af stærstu innlendu lífeyrissjóðunum, sem ekki eru í rekstri hjá fjármálafyrirtæki, reka eigin verðbréfasöfn og fjárfesta par af leiðandi ekki nema að litlu leyti innlendum verðbréfasjóðum.
} 
erlendum mörkuðum og einnig umsýslupóknun sem fengist fyrir að veita pessa pjónustu. Ef miðað er við 0,5\% umsýslupóknun má áætla að íslenskir lífeyrissjóðir greiði erlendum sjóðastýringarfyrirtækjum um 1,6 milljarða íslenskra króna á ári fyrir pessa pjónustu. Ef íslenskir lífeyrissjóðir myndu velja innlend fyrirtæki til að stýra pessum eignum sínum myndi pað auka pekkingu og reynslu peirra á erlendum mörkuðum. Aukin pekking og reynsla af erlendum mörkuðum gæti gefið innlendu sjóðastýringarfyrirtækjunum kost á að flytja út sína pjónustu í stað pess að kaupa hana erlendis frá.

Ætla má að val íslenskra lífeyrissjóða á sjóðastýringarfyrirtækjum byggist á gæðum pjónustunnar. Раð er hins vegar ekki alltaf auðvelt að meta gæði eignastýringar. Pess vegna vaknar sú spurning hvort innlend sjóðastýringarfyrirtæki séu í raun ekki samkeppnishæf við pau erlendu. Í pessari rannsókn er leitað svara við peirri spurningu með pví að bera saman gæði innlendra verðbréfasjóða með alpjóðlega fjárfestingarstefnu og sambærilegra erlendra sjóða.

Rannsókn pessi snertir á premur rannsóknarsviðum sem hafa öll verið könnuð erlendis en nánast ekkert verið skrifað um opinberlega á Íslandi. Í fyrsta lagi tengist hún rannsóknum á árangri verðbréfasjóða (Sjá til dæmis Malkiel (1995) og Wermers (2000)). Rannsóknarspurningin er reyndar ekki fyllilega sambærileg við helstu rannsóknir á pessu sviði að pví leyti að ekki er fjallað um árangur sjóða almennt heldur er verið að kanna hvernig íslenskir sjóðir koma út í samanburði við sambærilega erlenda sjóði.

Í öðru lagi fjallar rannsóknin um hvort jákvæð tengsl séu á milli lélegs árangurs og lokunar sjóða annars vegar og lélegs árangurs og nafnabreytinga á sjóðum hins vegar. Brown og Goetzmann (1995), Elton, Gruber og Blake (1996) og Lunde, Timmermann og Blake (1999) og Liang (2001) finna jákvæð tengsl milli lélegs árangurs og lokunar sjóða. Pá finna Cooper, Gulen og Rau (2005) aukið fjárflæði inn í sjóði sem hafa nýverið breytt nafni sínu yfir í nafn sem endurspeglar vinsæla fjárfestingarstefnu.

Í priðja og síðasta lagi fjallar rannsóknin um samanburð á kostnaði íslenskra og sambærilegra erlendra sjóða. Pónokkrar erlendar rannsóknir hafa beinst að kostnaði sjóða. Khorana, Servaes og Tufano (2007) finna töluverðan mismun á kostnaði milli landa. Niðurstöður peirra gefa meðal annars til kynna að kostnaður sé hærri í löndum par sem lagavernd fjárfesta er lakari. Pá sýna Barber, Odean og Zheng (2005) fram á að undanfarna prjá áratugi hefur mismunur á kaup- og sölugengi í Bandaríkjunum lækkað á sama tíma og árlegur umsýslukostnaður hefur hækkað. Peir telja að fjárfestar séu næmari gagnvart mismun á kaup- og sölugengi heldur en árlegum umsýslukostnaði.

Rannsóknin byggir fyrst og fremst á hefðbundinni aðferðafræði við mat á árangri verðbréfasjóða. Árangur er mældur samkvæmt meðalávöxtun og einnig leiðréttur með hliðsjón af peirri áhættu sem sjóðirnir bera. ${ }^{5}$ Til að bera íslenska sjóði saman við erlenda sjóði eru peir flokkaðir niður eftir fjárfestingarstefnum samkvæmt greiningarkerfi Morningstar og peir síðan bornir saman við erlenda sjóði sem tilheyra sama flokki.

Ritgerðin er byggð upp á eftirfarandi hátt: Fyrsti hluti lýsir gögnunum sem liggja til grundvallar og í öðrum hluta er fjallað um aðferðafræðina. Priðji hluti er um niðurstöður og í fjórða hluta eru helstu ályktanir dregnar saman.

${ }^{5}$ Sjá til dæmis: Sharpe (1966) og Jensen (1968). 


\section{Lýsing á gögnum}

Gögnin koma frá nokkrum upplýsingaveitum. Upplýsingar um íslenska verðbréfasjóði með alpjóðlega fjárfestingarstefnu koma frá sjóðastýringarfyrirtækjunum sjálfum. ${ }^{6}$ Pessir verðbréfasjóðir eru reknir af fjórum fyrirtækjum: Glitni (áður Íslandsbanki), Kauppingi (áður KB banki), Landsbanka Íslands og Sparisjóðunum (VSP). Úrtakið nær til 23 sjóða sem reknir eru af íslenskum fyrirtækjum; 14 voru starfræktir í árslok 2006 en níu hafa verið lagðir niður eða verið sameinaðir öðrum sjóðum. Úrtakið nær yfir átta ára tímabil (1999-2006) en flestir íslensku sjóðirnir voru stofnaðir seint á árinu 1998. Pessir sjóðir eru eða voru allir skráðir sem alpjóðlegir hlutabréfasjóðir samkvæmt flokkunarkerfi Lánstrausts hf. Til að tryggja gæði gagnanna voru pau uppfærð og staðfest af rekstraraðilum. Auk pess voru allar villur leiðréttar í samvinnu við rekstraraðila. Рað er pví óhætt að segja að gögnin um íslensku sjóðina séu eins fullkomin og raunhæft er.

Upplýsingar um erlenda sjóði eru frá Morningstar í Evrópu. Notast var við alla sjóði sem pað fyrirtæki safnar gögnum fyrir og voru starfræktir í lok árs 2006. Gagnagrunnurinn inniheldur bæði evrópska og svokallaða „offshore“ verðbréfasjóði.7 Ekki reyndist unnt að fá upplýsingar um sjóði sem voru lagðir niður á tímabilinu. Höfundum er ekki kunnugt um neina upplýsingaveitu sem safnar pess háttar upplýsingum fyrir evrópska verðbréfasjóði.

Viðmiðunarvísitölur eru frá Morgan Stanley Capital International (MSCI) og voru sóttar í gegnum Datastream. Viðmiðunarvísitölur sem voru notaðar fyrir hverja fjárfestingarstefnu eru pær sömu og Morningstar styðst við í sinni greiningu.

Rannsóknin er byggð á mánaðarlegum ávöxtunartölum (að teknu tilliti til árlegs umsýslukostnaðar) sem hafa verið umreiknaðar yfir í evrur til að gera ávöxtunartölur allra sjóða sambærilegar. Par með er búið að eyða áhrifum gengisbreytinga á ávöxtun íslenskra fjárfesta. Pess ber að geta að flestir íslensku sjóðirnir og um 90\% erlendu sjóðanna eru gerðir upp í evrum svo að pessi forsenda hefur ekki afgerandi áhrif á niðurstöðurnar. Samkvæmt sampykktum sjóðanna mega allir íslensku sjóðirnir (fyrir utan sjóði VSP) nota afleiður til að verja gjaldeyrisáhættu. Formlegar og óformlegar heimildir frá fyrirtækjunum sjálfum gefa hins vegar til kynna að ekki sé lögð mikil áhersla á petta hjá peim sjóðum og yfir pað tímabil sem er til skoðunar í pessari rannsókn.

Tafla 1 gefur yfirlit yfir flokkun og fjölda sjóða. Flestir íslensku sjóðirnir voru enn pá starfræktir í lok tímabilsins og um helmingur peirra starfræktur yfir allt tímabilið (1999_ 2006). ${ }^{8}$ Einu sjóðirnir sem ekki voru starfræktir í árslok 2006 voru atvinnugreinasjóðir Glitnis og atvinnugreinasjóðir VSP. Sjóðir Glitnis voru sameinaðir Global Equity en sjóðum VSP var öllum lokað fyrir árslok 2006. Taka purfti sérstakt tillit til lokana á sjóðum og nafnabreytinga en hvort tveggja var nokkuð algengt hjá íslensku sjóðunum á tímabilinu. ${ }^{9}$ I flestum tilvikum urðu pessar breytingar í kjölfar sameiningar Kauppings og Búnaðarbanka Íslands árið 2003.

\footnotetext{
${ }^{6}$ Sjá nánari lýsingu í ritgerð Kára, Söru og Valgerðar (2006).

${ }^{7}$ Allir íslenskir sjóðir voru fjarlægðir úr gagnagrunninum.

${ }^{8}$ Tafla 1 inniheldur ítarlegra yfirlit yfir starfstíma sjóðanna. Í rannsókninni var notast við gögn um alla sjóðina nema Kaupping - Erlend hlutabréf. Ekki var hægt að nálgast ávöxtunartölur á samfelldu formi fyrir pann sjóð.

${ }^{9}$ Með lokuðum sjóðum er bæði átt við sjóði sem hefur verið lokað og sjóði sem hafa verið sameinaðir öðrum. Pegar tveir eða fleiri sjóðir sameinast í einn er metið hvort sjóðunum hefur verið lokað eða hvort nýr sjóður tekur með sér einhverja sögu. Ef nýr sjóður tekur með sér sögu eins af sjóðunum er litið svo á að sá sjóður sé enn starfræktur. Hinir sjóðirnir eru hins vegar skilgreindir sem lokaðir enda ekkert framhald á peirra sögu.
} 
Upp komu dæmi par sem sjóðir skiptu um nafn oftar en einu sinni á tímabilinu sem skoðað var. Nánar verður fjallað um petta atriði í niðurstöðum um tengsl árangurs við lokanir og nafnabreytingar.

Í töflu 1 kemur fram að í flestum tilvikum var aðeins einn íslenskur sjóður undir hverri fjárfestingarstefnu en töluverður fjöldi erlendra sjóða. Nánar er farið í flokkun sjóða og gerð samanburðarmengja í næsta kafla.

Vert er að geta pess að um priðjungur íslensku sjóðanna fjárfesta í erlendum sjóðum og eru pví oft nefndir sjóðasjóðir. Pessir sjóðir eru KMS og KIF sjóðir Kauppings, Heimssafn Glitnis og Global Equity Fund hjá Landsbankanum. Global Opportunity Fund hjá Landsbankanum fjárfestir jafnframt bæði í sjóðum og hlutabréfum. Markmið sjóðasjóða og sjóða sem fjárfesta í hlutabréfum milliliðalaust er pað sama og pví voru pessar tegundir sjóða ekki aðskildar í greiningunni.

Erlendis er pað pekkt fyrirbæri að líkurnar á pví að sjóðum sé lokað aukast eftir pví sem árangurinn er lakari. Petta gerir pað að verkum að söguleg meðalávöxtun sjóða sem enn eru starfræktir er bjöguð upp á við og pví verða rannsóknir sem fjalla um árangur verðbréfasjóða að taka tillit til allra sjóða sem hafa verið starfræktir á tímabilinu. Erlendu gögnin sem liggja til grundvallar pessari rannsókn ná hins vegar einungis til sjóða sem eru enn pá starfræktir og eru pví sennilega bjöguð á pennan hátt. Mælingar á árangri íslensku sjóðanna með fjárfestingarstefnu skilgreinda eftir landsvæðum innihalda einungis sjóði sem eru enn pá starfræktir. Bjögunin er pví sambærileg í báðum tilfellum og pví ekki ástæða til að ætla að hún hafi tiltekin áhrif á niðurstöðuna. Íslensku atvinnugreinasjóðirnir eru hins vegar ekki starfræktir í dag og pví má ætla að samanburðurinn við erlendu sjóðina sé íslensku sjóðunum í óhag. Petta atriði getur hugsanlega haft áhrif á niðurstöðuna í pessu tilfelli en eins og áður hefur komið fram reyndist ekki unnt að fá gögn fyrir erlenda sjóði sem hefur verið lokað. 
Tafla 1.Yfirlit yfir flokkun og fjölda sjóða. ${ }^{10}$

\begin{tabular}{|c|c|c|c|c|}
\hline & \multicolumn{2}{|c|}{ Alpjóðleg hlutabréf } & \multicolumn{2}{|c|}{ Alpjóðleg vaxtarfyrirtæki } \\
\hline & \multicolumn{2}{|c|}{ MSCI The World Free } & \multicolumn{2}{|c|}{ MSCI The World Free Growth } \\
\hline Tímabil & $2002-2006$ & 1999-2006 & $2005-2006$ & $2004-2006$ \\
\hline Fjöldi íslenskra sjóða & 5 & 3 & 1 & 1 \\
\hline Fjöldi erlendra sjóða & 622 & 225 & 43 & 43 \\
\hline \multirow[t]{6}{*}{ Nöfn íslenskra sjóða } & \multirow{4}{*}{\multicolumn{2}{|c|}{$\begin{array}{c}\text { Glitnir - Heimsafn, Glitnir - Global } \\
\text { Equity, Kaupping - KMS Global Styles, } \\
\text { Kaupping - KIF Global Equity og } \\
\text { Kaupping - KIF Bric }{ }^{*}\end{array}$}} & \multirow{4}{*}{\multicolumn{2}{|c|}{ Kaupping - Global Equities** }} \\
\hline & & & & \\
\hline & & & & \\
\hline & & & & \\
\hline & \multicolumn{2}{|c|}{ Alpjóðleg verðmæt fyrirtæki } & & \\
\hline & \multicolumn{2}{|c|}{ MSCI The World Free Value } & \multicolumn{2}{|c|}{ MSCI AC Asia Pacific } \\
\hline Tímabil & $2005-2006$ & $2004-2006$ & $2002-2006$ & $1999-2006$ \\
\hline Fjöldi íslenskra sjóða & 1 & 1 & 1 & 1 \\
\hline Fjöldi erlendra sjóða & 63 & 63 & 75 & 42 \\
\hline \multirow[t]{3}{*}{ Nöfn íslenskra sjóða } & \multicolumn{2}{|c|}{ Kaupping - Global Value } & \multicolumn{2}{|c|}{ Kaupping - KMS Asia Pacific } \\
\hline & \multicolumn{2}{|c|}{ Evrópa } & \multicolumn{2}{|c|}{ Norður-Ameríka } \\
\hline & \multicolumn{2}{|c|}{ MSCI Europe } & \multicolumn{2}{|c|}{ MSCI North America } \\
\hline Tímabil & $2002-2006$ & 1999-2006 & $2002-2006$ & $1999-2006$ \\
\hline Fjöldi íslenskra sjóða & 1 & 1 & 1 & 1 \\
\hline Fjöldi erlendra sjóða & 356 & 154 & 232 & 106 \\
\hline \multirow[t]{3}{*}{ Nöfn íslenskra sjóða } & \multicolumn{2}{|c|}{ Kaupping - KMS Europe } & \multicolumn{2}{|c|}{ Kaupping - KMS N-America } \\
\hline & \multicolumn{2}{|c|}{ Norðurlönd } & \multicolumn{2}{|c|}{ Nýmarkaðir } \\
\hline & \multicolumn{2}{|c|}{ MSCI Nordic Countries } & \multicolumn{2}{|c|}{ MSCI Emerging Markets } \\
\hline Tímabil & $2003-2006$ & $2001-2006$ & $2002-2006$ & $1999-2006$ \\
\hline Fjöldi íslenskra sjóða & 1 & 1 & 1 & 1 \\
\hline Fjöldi erlendra sjóða & 50 & 37 & 95 & 49 \\
\hline \multirow[t]{3}{*}{ Nöfn íslenskra sjóða } & \multicolumn{2}{|c|}{ Kaupping - Nordic Growth } & Kaupping $-\mathrm{I}$ & rging Markets \\
\hline & Fjár & tæki & & \\
\hline & $\overline{\mathrm{MSCI}}$ & inance & $\overline{\text { MSCI W }}$ & alth Care \\
\hline Tímabil & $2003-2004$ & $2001-2004$ & $2003-2004$ & $2001-2004$ \\
\hline Fjöldi íslenskra sjóða & 2 & 2 & 2 & 2 \\
\hline Fjöldi erlendra sjóða & 58 & 44 & 85 & 69 \\
\hline & Glitı & rmál & Glit & eilsa \\
\hline Nöfn íslenskra sjóða & VSP $-\mathrm{I}$ & jóðurinn & VSP - Lyf- & knisjóðurinn \\
\hline & Tæ & æki & & \\
\hline & $\overline{\mathrm{MSCI}}$ & fo Tech & & \\
\hline Tímabil & $2003-2004$ & $2001-2004$ & & \\
\hline Fjöldi íslenskra sjóða & 2 & 2 & & \\
\hline Fjöldi erlendra sjóða & 164 & 142 & & \\
\hline & Glit & ekni & & \\
\hline Nöfn íslenskra sjóða & VSP $-\mathrm{H}$ & jóðurinn & & \\
\hline
\end{tabular}

*Kaupping - KIF Bric er flokkaður sem alpjóðlegur sjóður par sem fjárfestingarviðmið hans er MSCI-heimsvísitalan. Pó svo að BRIC-löndin hafi mest vægi í safninu fjárfestir sjóðurinn einnig í öðrum löndum.

**Kaupping - Global Equities hefur fjárfestingarviðmiðið „,MSCI heimsvaxtarfyrirtæki“ prátt fyrir að nafnið gefi

\footnotetext{
${ }^{10}$ Nafn viðmiðunarvísitölu er fyrir neðan nafn á fjárfestingarstefnu.
} 


\section{Aðferðafræði}

Eins og áður hefur komið fram eru íslensku sjóðirnir bornir saman við sambærilega erlenda sjóði samkvæmt vel pekktum árangursmælikvörðum. Í pessum kafla verður samanburðarmenginu og árangursmælikvörðunum lýst nánar.

\subsection{Samanburðarmengi}

Samanburðarmengi fyrir hverja fjárfestingarstefnu er búið til samkvæmt flokkunarkerfi Morningstar. Heildarfjöldi samanburðarsjóða frá Morningstar í árslok 2006 voru 1.843 sjóðir sem dreifðust yfir 11 fjárfestingarstefnur. Í flestum fjárfestingarstefnum er einungis einn íslenskur sjóður en í fjórum stefnum eru peir fleiri. Í töflu 1 má sjá yfirlit yfir samanburðarmengin, hvaða íslensku sjóðir tilheyra hvaða mengi og fjölda sjóða fyrir pau tímabil sem valin voru til skoðunar. Annað tímabilið er haft eins langt og mögulegt er til að mæla árangur við mismunandi efnahagsaðstæður. Hitt tímabilið er haft aðeins styttra til að fá stærra samanburðarmengi en samanburðarsjóðunum fækkar eftir pví sem tímabilið lengist. Par sem íslensku sjóðirnir voru starfræktir yfir mismunandi tímabil purfti að taka ákvörðun um samanburðartímabil sérstaklega fyrir hverja og eina fjárfestingarstefnu. Stuðst var við pá reglu að nota fimm og átta ára tímabil pegar hægt var en annars voru valin tvö önnur tímabil sem samsvöruðu líftíma íslensku sjóðanna. Rannsóknartímabilið hefst í ársbyrjun 1999 og nær yfir átta ára samfellt tímabil, eða til ársloka 2006. Fimm fjárfestingarstefnur innihéldu íslenska sjóði sem höfðu verið starfræktir yfir allt tímabilið. Í hinum tilvikunum purfti að skilgreina tímabil miðað við líftíma íslensku sjóðanna.

Fjárfestingarstefnurnar Alpjóðleg vaxtarfyrirtæki og Alpjóðleg verðmæt fyrirtæki innihéldu báðar aðeins einn íslenskan sjóð sem hafði einungis verið starfræktur í prjú ár. Pví var ákveðið að skoða samanburð yfir tveggja og priggja ára tímabil. Samskonar staða kom upp með fjárfestingarstefnuna Norðurlönd. Par var einungis einn íslenskur sjóður sem hafði verið starfræktur í sex ár. Í pví tilfelli var ákveðið að skoða fjögurra og sex ára tímabil. Íslensku sjóðirnir sem tilheyra atvinnugreinum (Fjármála-, Lyfja- og Tæknifyrirtæki) voru heldur ekki starfræktir yfir allt tímabilið. Í hverri stefnu voru tveir íslenskir sjóðir starfandi. Sjóðir Glitnis (Fjármál, Heilsa og Tækni) voru starfandi á árunum 2001-2004 en sjóðir VSP (Fjármála-, Hátækni- og Lyf- og líftæknisjóðurinn) frá árinu 2000 fram yfir mitt ár 2006. Til að geta borið tvo íslenska sjóði saman við samanburðarmengið var ákveðið að skoða tvö tímabil, annars vegar 2001-2004 (fjögurra ára tímabil) og hins vegar 2003-2004 (tveggja ára tímabil). Aðrar fjárfestingarstefnur var hægt að skoða yfir allt tímabilið.

\section{2 Árangursmælikvarðar}

Til viðbótar við meðaltal mánaðarlegrar ávöxtunar og heildaráhættu er frammistaða verðbréfasjóðanna jafnframt metin með tvenns konar aðferðum. Fyrri aðferðin byggir á pví að meta eftirfarandi aðhvarfsjöfnu sem svipar til CAPM-líkansins:

$$
R_{s, m}-R_{r f, m}=\alpha_{s}+\beta_{s}\left(R_{M S C l, m}-R_{r f, m}\right)+\varepsilon_{s, m}
$$

par sem $\left(R_{s, m}-R_{r f, m}\right)$ er umframávöxtun sjóðs $s$ í mánuði $m$ og $\left(R_{M S C l, m}-R_{r f, m}\right)$ er umframávöxtun viðmiðunarvísitölu í mánuði $m$. Hallatalan $(\beta)$ mælir kerfisbundna áhættu sjóðsins og skurðpunkturinn $\left(\alpha_{s}\right)$ mælir ávöxtun sem er umfram pá áhættupóknun sem kerfisbundna áhættan spáir fyrir um. Skurðpunkturinn er gjarnan kenndur við Jensen (1969). Staðalfrávik afgangsliðsins $\left(\sigma_{\varepsilon}\right)$ er notað til að meta sértæka áhættu (e. residual risk) en pað er sú áhætta sem eftir er pegar búið er að taka tillit til kerfisbundinnar áhættu. 
Seinni aðferðin við að mæla árangur er vísitala Sharpe (1966):

(2) $\frac{\bar{R}_{s, m}-\bar{R}_{r f}}{\sigma_{s, m}}$

par sem $\bar{R}_{s, m}$ er meðaltal mánaðarlegrar ávöxtunar sjóðs $s$ og $\bar{R}_{r f}$ er meðaltal mánaðarlegrar ávöxtunar á peningamarkaði fyrir evrur (notað sem mælikvarði fyrir áhættulausa ávöxtun). $\sigma_{s, m}$ er heildaráhætta sjóðs $s$ mæld sem staðalfrávik á mánaðarávöxtun. Vísitala Sharpes leiðréttir árangur fyrir heildaráhættu sjóða. Með heildaráhættu er átt við bæði kerfisbundna $(\beta)$ og sértæka áhættu $\left(\sigma_{\varepsilon}\right)$. $^{11}$

\section{Niðurstöður}

Niðurstöðum rannsóknarinnar er skipt niður í prjá hluta. Í fyrsta hluta er gerður samanburður á áhættu og árangri íslensku og erlendu sjóðanna. Í öðrum hluta er fjallað um íslenska sjóði sem hefur verið lokað eða hafa breytt um nafn á rannsóknartímabilinu og í priðja og síðasta hlutanum er gerður samanburður á kostnaði íslensku og erlendu sjóðanna.

\subsection{Samanburður á áhættu og árangri}

Mynd 2 sýnir meðalársávöxtun sjóða í hverri fjárfestingarstefnu yfir mismunandi tímabil. Efri (neðri) brún á hverjum kassa merkir að 95\% (5\%) sjóðanna í samanburðarmenginu eru undir peirri ávöxtun. Punktastrik eru svo sett við 75\%-, 50\%- og 25\%-mörkin. Litaður kassi merkir meðalávöxtun viðmiðunarvísitölu fyrir viðkomandi fjárfestingarstefnu og tígull merkir meðalávöxtun íslensku sjóðanna sem tilheyra fjárfestingarstefnunni.

Íslensku sjóðirnir standa sig misvel gagnvart samanburðarmengjunum. Í fimm tilvikum af 22 eru peir yfir 75\%-mörkunum sem er örlítið verri útkoma heldur en að meðaltali hjá erlendu sjóðunum. Hins vegar eru íslensku sjóðirnir yfir 50\%-mörkunum í 12 tilvikum sem er heldur betri útkoma en að meðaltali hjá peim erlendu. Íslensku sjóðirnir eru síðan yfir 25\%-mörkunum í alls 18 tilvikum af 22 sem er einnig aðeins betri útkoma heldur en hjá peim erlendu. Enginn íslenskur sjóður er svo slakur að hafna undir 5\%-mörkunum.

Greinilegt er að talsverður munur er á gengi íslensku sjóðanna eftir fjárfestingarstefnum en á heildina litið skila íslensku sjóðirnir örlítið hærri meðalávöxtun en sambærilegir erlendir sjóðir. Erfitt er að skýra hvað veldur pví að íslenskir sjóðir skila góðum árangri innan einnar fjárfestingarstefnu og lökum árangri innan annarrar stefnu. Ef til vill eru fjárfestingarákvarðanir innan íslensku fyrirtækjanna ekki teknar á staðlaðan hátt fyrir allar fjárfestingarstefnur og pví getur tilviljun haft áhrif á útkomuna.

Pegar skoðaður er samanburður á sjóðunum og viðmiðunarvísitölunni kemur í ljós að í 12 tilvikum af 22 hefur viðmiðunarvísitalan gefið betri meðalávöxtun en íslensku sjóðirnir. Íslensku sjóðirnir hafa einungis staðið sig betur í sex tilvikum og skilað sambærilegri ávöxtun í fjórum tilvikum. Á heildina litið hefur vísitalan skilað hærri ávöxtun að meðaltali. Í peim tilvikum sem íslensku sjóðirnir standa sig betur er munurinn mjög lítill og varla marktækur (sjá mynd 2). Pess ber pó að geta að arðgreiðslur eru að fullu innifaldar í vísitölunni á meðan íslensku sjóðirnir purfa að greiða skatt af arðgreiðslum.

11 Kerfisbundin áhætta er líka kölluð markaðsáhætta og sértæk áhætta er stundum kölluð fyrirtækjabundin áhætta. 
Mynd 2. Samanburður á meðalávöxtun (\% á ári) innan fjárfestingarstefna.

Myndin sýnir meðalársávöxtun sjóða í hverri fjárfestingarstefnu yfir mismunandi tímabil. Efri (neðri) brún á hverjum kassa merkir að 95\% (5\%) sjóðanna í samanburðarmenginu eru undir peirri ávöxtun. Punktastrik eru svo sett við 75\%, 50\% og 25\%-mörkin. Litaður kassi merkir meðalávöxtun viðmiðunarvísitölu fyrir viðkomandi fjárfestingarstefnu og tígull merkir meðalávöxtun íslensku sjóðanna sem tilheyra fjárfestingarstefnunni.
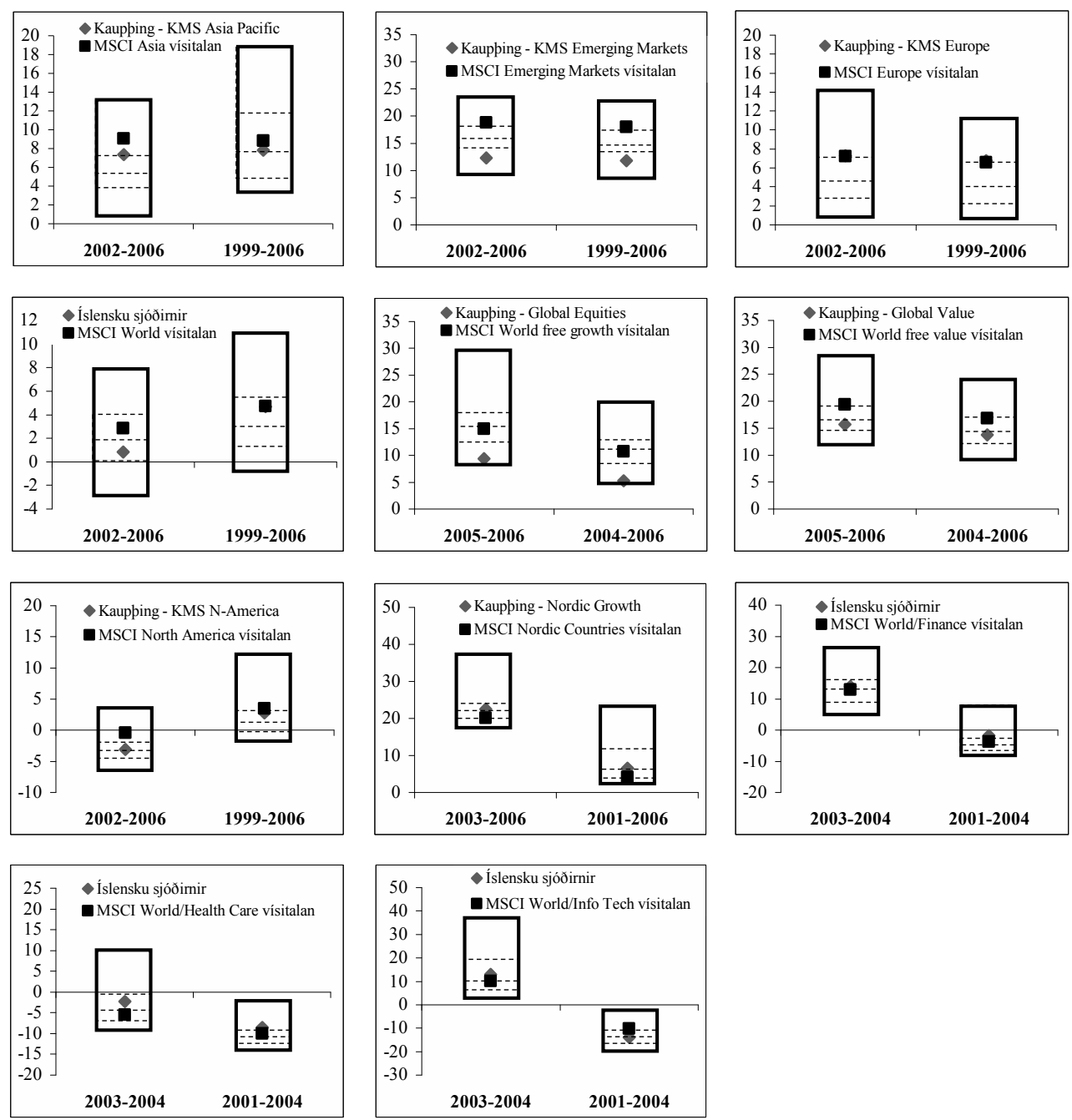
Tafla 2 sýnir heildarsamanburð á íslensku og erlendu verðbréfasjóðunum eftir mismunandi árangursmælikvörðum. Eins og áður er töflunum skipt niður eftir fjárfestingarstefnum og rannsóknartímabilum. Fyrstu dálkarnir fyrir hvert tímabil sýna samanburð á meðalávöxtun og á heildaráhættu. Taflan inniheldur jafnframt mat á ölfu $(\hat{\alpha})$ og vísitölu Sharpe. Alfa er mælikvarði á hæfni sjóðstjóra til að velja rétt hlutabréf í verðbréfasöfn sín (e. stock picking ability) og ná pannig hærri ávöxtun heldur en vænt áhættupóknun fyrir kerfisbundna áhættu. Vísitala Sharpes mælir árangur sjóðs að teknu tilliti til heildaráhættu. Í töflunni er áhættu einnig skipt í kerfisbundna $(\hat{\beta})$ og í sértæka áhættu $\left(\hat{\sigma}_{\varepsilon}\right)$.

\subsection{1 Áhætta}

Niðurstöður í töflu 2 sýna að íslensku sjóðirnir taka meiri heildaráhættu ( $\left.\sigma_{\text {Total\% }}\right)$ en peir erlendu í 16 af 22 tilvikum sem er vísbending um að íslensku sjóðirnir séu í heild áhættumeiri. Jafnframt kemur fram að mismunur á kerfisbundinni áhættu sjóðanna $(\hat{\beta})$ er marktækur í 10 tilvikum af 22 og í öll skiptin er áhætta íslensku sjóðanna meiri (Asía yfir fimm og átta ár, Nýmarkaðir yfir fimm ár, Evrópa yfir fimm og átta ár, Alpjóðleg hlutabréf yfir fimm og átta ár, Norður-Ameríka yfir átta ár og Norðurlönd yfir fjögur og sex ár). I fimm tilvikum er munurinn marktækur við $1 \%$ marktektarkröfu og í hinum fimm tilvikunum við 10\% marktektarkröfu. Af pessum niðurstöðum má draga pá ályktun að kerfisbundin áhætta íslensku sjóðanna sé að öllu jöfnu meiri en hjá peim erlendu.

Taflan gefur einnig til kynna að íslenskir sjóðir séu nokkuð sambærilegir við pá erlendu pegar kemur að sértækri áhættu $\left(\sigma_{\varepsilon}\right)$. Í 11 tilvikum af 22 er áhættan meiri og í 11 tilvikum minni. Рað ber pó að taka fram að í premur tilvikum par sem íslensku sjóðirnir bera meiri sértæka áhættu er mismunurinn talsvert mikill. Íslenskir sjóðir með fjárfestingarstefnuna Alpjóðleg hlutabréf báru 1,08 prósentustigum meiri áhættu á mánuði yfir tímabilið 1999_ 2006. Sömu sögu má segja um íslenska sjóði í fjárfestingarstefnunni Norðurlönd, yfir tímabilin 2003-2006 og 2001-2006 en par var áhættan meiri sem nemur 1,25 og 0,95 prósentustigum. Ef til vill er petta vegna pess að íslensku sjóðirnir innihalda færri fyrirtæki að meðaltali samanborið við erlenda sjóði sem tilheyra stærri sjóðastýringarfyrirtækjum. Stór sjóðastýringarfyrirtæki reka umsvifamiklar greiningardeildir og purfa gjarnan til að fjárfesta í mörgum fyrirtækjum ef um stóran sjóð er að ræða.

Í heild gefa niðurstöður til kynna að íslensku sjóðirnir taki meiri heildaráhættu og almennt skýrist pað fyrst og fremst af aukinni kerfisbundinni áhættu. 


\subsection{2 Ávöxtun}

Tafla 2 sýnir að í fjórum tilvikum af 22 er marktækur munur á ölfum íslensku og erlendu sjóðanna (Nýmarkaðir yfir fimm ár, Alpjóðleg hlutabréf yfir fimm ár og Alpjóðleg verðmæt hlutabréf yfir tvö og prjú ár). Í öll skiptin hafa íslensku sjóðirnir lægri ölfu og í tilfelli Alpjóðlegra verðmætra hlutabréfa er munurinn um 6\% á ársgrundvelli. Mismunurinn er í einu tilviki marktækur við 1\% marktektarkröfu (Nýmarkaðir yfir fimm ár) og í hinum fjórum tilvikunum er munurinn marktækur við 5\% kröfu. Ef horft er fram hjá marktektarkröfum kemur í ljós að í 50\% tilvika eru íslensku sjóðirnir með hærri ölfur en erlendu sjóðirnir. Í ljósi pessara niðurstaðna má pví segja að íslensku sjóðirnir séu að skila svipuðum árangri og erlendu sjóðirnir samkvæmt pessum mælikvarða.

Ef vísitala Sharpe er notuð sem árangursmælikvarði sýna íslensku sjóðirnir betri árangur í 10 tilvikum af 22 (Asía yfir fimm ár, Evrópa yfir fimm og átta ár, Alpjóðleg hlutabréf yfir átta ár, Fjármálafyrirtæki yfir tvö og fjögur ár, Lyfjafyrirtæki yfir tvö og fjögur ár, Tæknifyrirtæki yfir tvö ár og Norður-Ameríka yfir átta ár). Í tveimur tilvikum skila sjóðirnir sambærilegum árangri en í 10 tilvikum er hann lakari. Niðurstaðan samkvæmt pessum mælikvarða er pví sú sama og áđur, p.e. íslensku sjóðirnir skila svipuðum árangri og peir erlendu. 


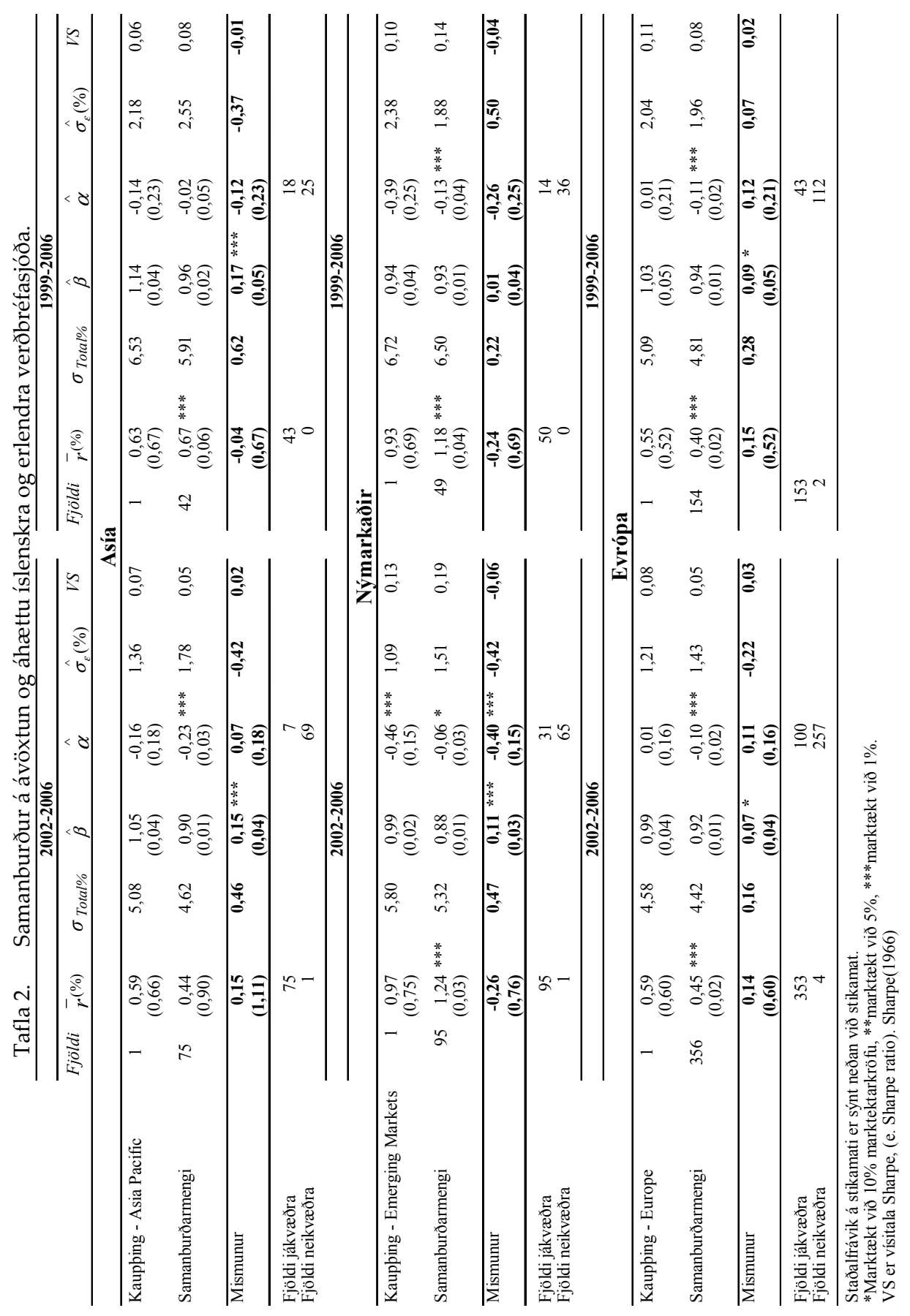




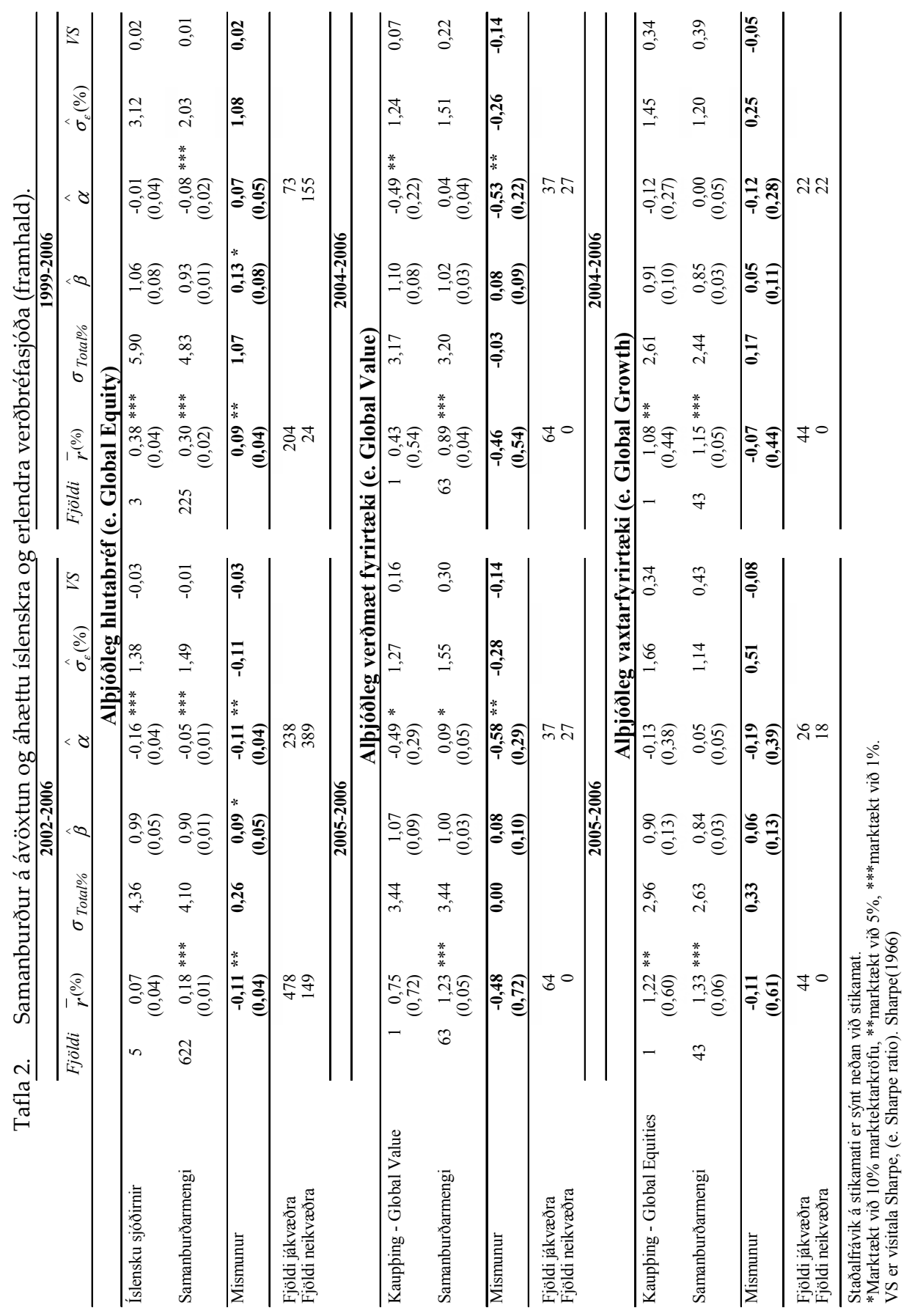




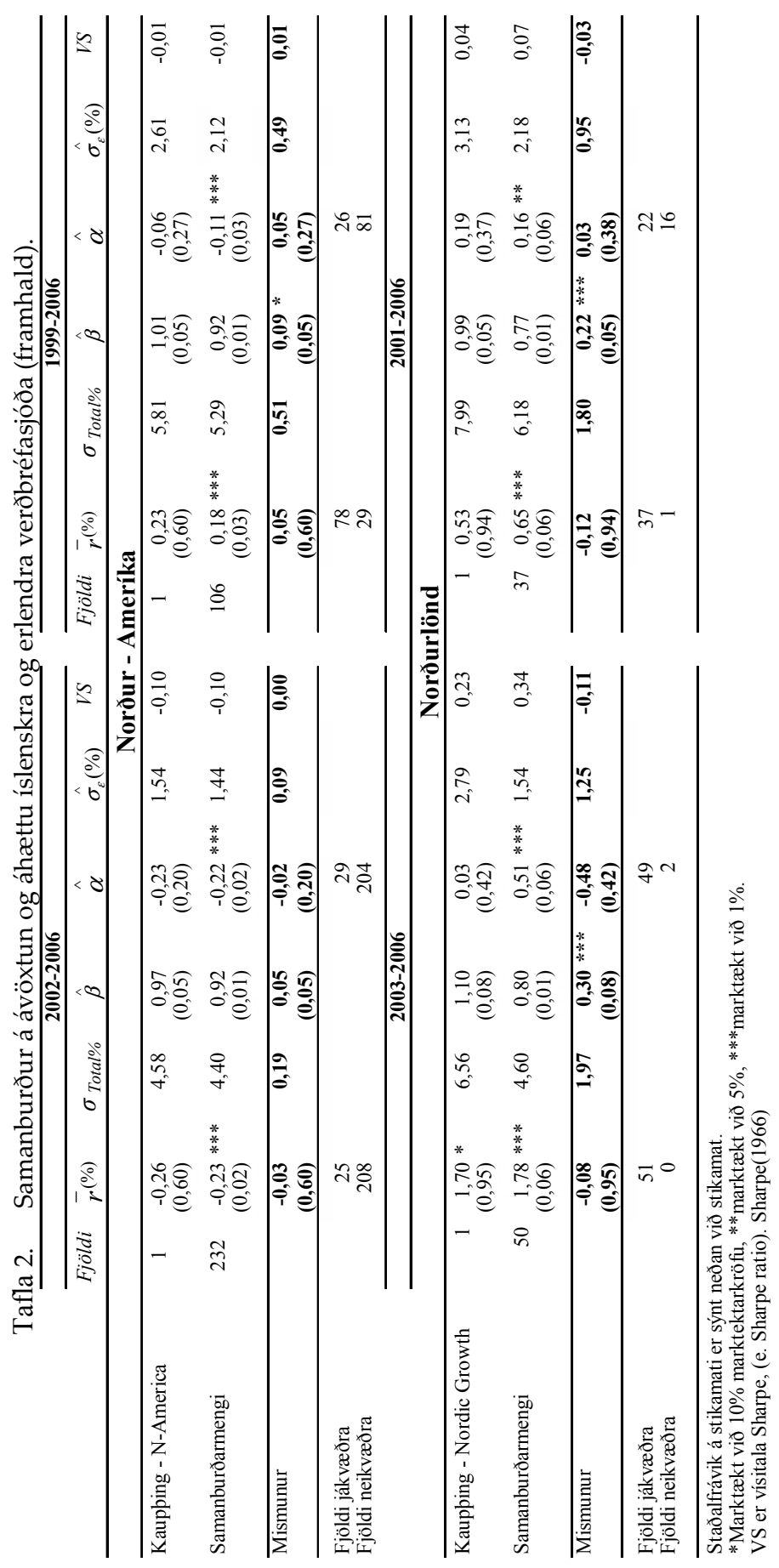




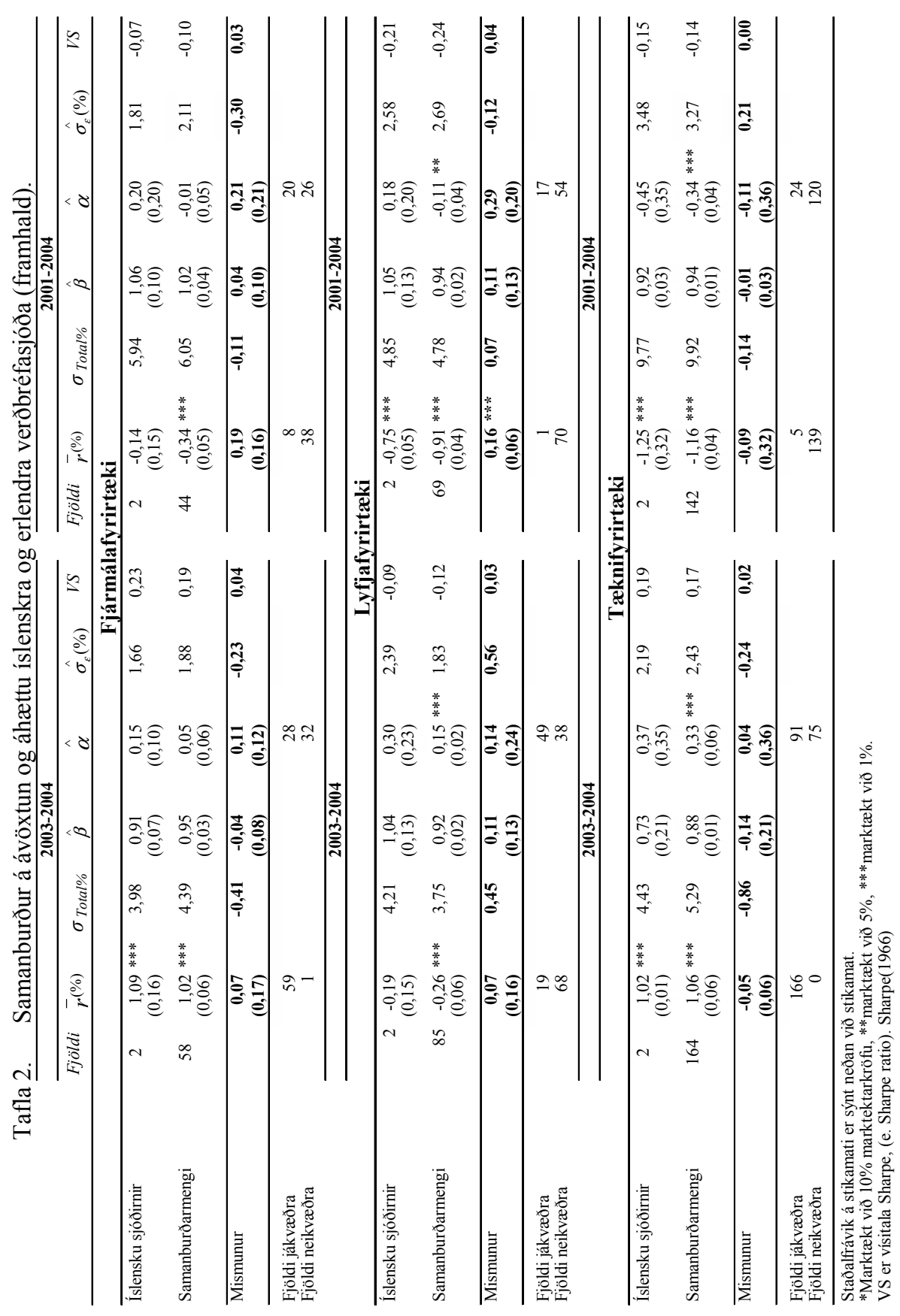




\subsection{Lokanir og nafnabreytingar á íslenskum sjóðum}

Í bandarískum sjóðastýringariðnaði hafa rannsóknir sýnt fram á að líkurnar á pví að sjóðum sé lokað aukast eftir pví sem árangurinn er verri (Brown og Goetzmann (1995), Elton, Gruber og Blake (1996), Lunde, Timmermann og Blake (1999) og Liang (2001)). Í Bandaríkjunum er jafnframt pekkt fyrirbæri að nöfnum á sjóðum er stundum breytt til að endurspegla tísku í fjárfestingarstefnum og laða að nýja fjárfesta (Cooper, Gulen og Rau (2005)). Afleiðingin af lokun sjóða í kjölfar lélegs árangurs getur verið ofmat á meðaltalsávöxtun sjóða ef mælt er með sýni sem inniheldur einungis sjóði sem enn eru starfræktir. Petta atriði er hins vegar ekki mikilvægt í okkar tilviki par sem pessi rannsókn fjallar fyrst og fremst um samanburð á árangri erlendra og íslenskra sjóða sem eru enn starfræktir í dag. Рað er pó athyglisvert í ljósi erlendra rannsóknarniðurstaðna að skoða sérstaklega nafnabreytingar, sameiningu og árangur peirra íslensku sjóða sem lokað var á tímabilinu. Mynd 3 sýnir áhrif pess á meðalávöxtun íslenskra sjóða að skoða einungis sjóði sem eru starfræktir í dag. Eins og sjá má hefur petta lítil áhrif á meðalávöxtun, ólíkt niðurstöðum úr erlendum rannsóknum.

Mynd 3. Bjögun í ávöxtunartölum vegna sjóða sem eru ekki lengur starfræktir.

Allir sjóðir: Glitnir - Heimssafn, Kaupping - KMS Global Styles, Kaupping - KIF Global Equity, Kaupping - KIF Bric, Landsbanki - Global Equity fund, Landsbanki - Global Opportunity fund, Glitnir - Sjóður 14, Kaupping - Global Equity Class, VSP - Alpjóðasjóðurinn.

Enn pá starfræktir: Glitnir - Heimssafn, Kaupping - KMS Global Styles, Kaupping - KIF Global Equity, Kaupping - KIF Bric, Landsbanki - Global Equity fund, Landsbanki - Global Opportunity fund.

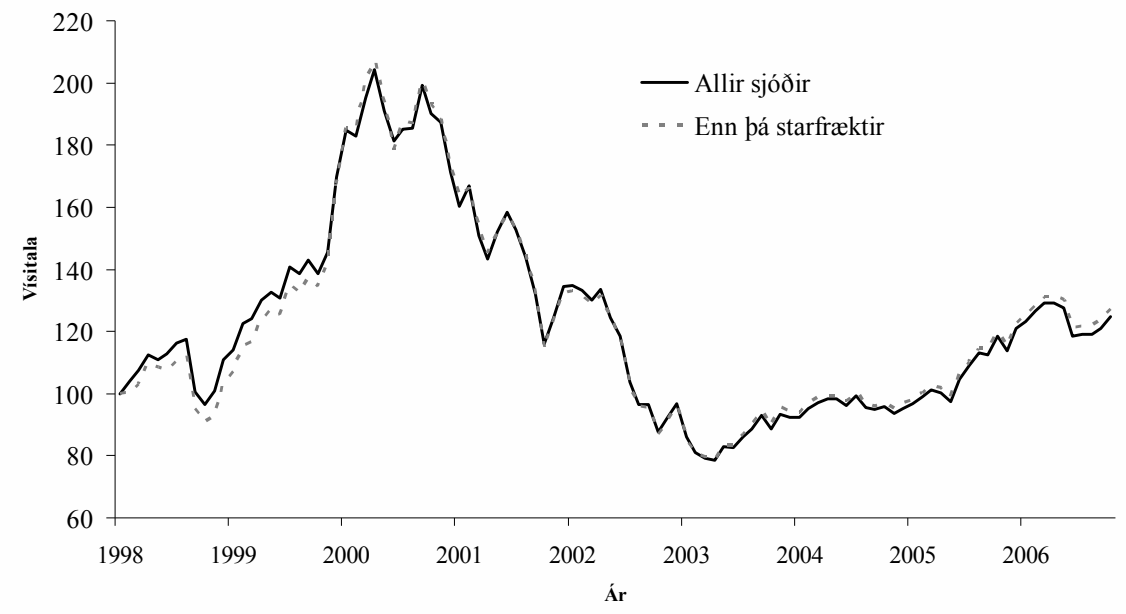


Tafla 4 gefur yfirlit yfir lokanir, sameiningu og nafnabreytingar á íslensku sjóðunum. Átta nafnabreytingar urðu á tímabilinu, flestar vegna sameiningar Kauppings og Búnaðarbanka Íslands. Í fjórum tilfellum voru sjóðir sameinaðir og alls var sjö sjóðum lokað.

Atvinnugreinasjóðir Glitnis (Fjármál, Heilsa, Lífstíll og Tækni) voru allir sameinaðir við Global Equity í árslok 2004. Nafnbreyting varð á Sjóð 12 og heitir hann Heimssafn í dag. Bæði Sjóð 13 og Sjóð 14 var lokað í júlí árið 2001. ${ }^{12}$ Við sameiningu Kauppings og Búnaðarbanka Íslands urðu nafnabreytingar á mörgum sjóðum. Alls voru sjö sjóðir sem breyttu um nafn. Tveir sjóðir gengu inn í Global Sector sem síðar var breytt í KIF Bric. Global Growth var búinn til úr sjóðunum Global Equity Class og Global Technology Class í byrjun árs 2004. International Equity breytti um nafn árið 2004 og heitir í dag KMS Global Styles. Um mitt ár 2005 sameinaðist svo Tech \& Health peim sjóði líka. ${ }^{13}$ Hjá VSP var öllum fjórum sjóðunum lokað í ágúst 2006. Pessir sjóðir höfðu allir verið starfræktir yfir jafn langan tíma, eða frá apríl árið 2000 út ágústmánuð 2006. ${ }^{14}$

Til að kanna nánar árangur peirra sjóða sem var lokað á rannsóknartímabilinu ${ }^{15}$ var reiknuð meðalávöxtun sjóðanna að frádreginni meðalávöxtun á viðmiðunarvísitölu yfir tvö ár áður en peim var lokað. Tölurnar voru síðan bornar saman við sambærilegar tölur fyrir pá sjóði sem enn eru starfræktir. Tafla 3 inniheldur niðurstöðurnar og par kemur fram að í sex tilvikum af átta sýndu sjóðirnir sem var lokað betri árangur en peir sem enn eru starfræktir. Í heildina skiluðu lokaðir sjóðir 0,11\% hærri ávöxtun á mánuði eða um 1,3\% á ársgrundvelli umfram viðmiðunarvísitölu og pví er ekki tilefni til að álykta að ástæður lokana hafi verið lélegur árangur gagnvart öðrum íslenskum sjóðum né erlendum sjóðum. Ekki virðast pví vera jákvæð tengsl milli lokana sjóða og lélegs árangurs líkt og erlendar rannsóknir hafa leitt í ljós.

\footnotetext{
12 Samkvæmt upplýsingum frá framkvæmdastjóra Glitnis sjóða hf. er ástæðan fyrir sameiningu atvinnugreinasjóðanna við Global Equity sú að íslenskir lífeyrissjóðir vilja langflestir fjárfesta í alpjóðlegum sjóðum frekar en atvinnugreina eða landsvæðabundnum sjóðum. Framkvæmdastjóri Glitnis sjóða hf. sagði einnig að ástæðan fyrir nafnabreytingu á Sjóð 12 væri sú að nafnið Heimssafn væri meira lýsandi fyrir sjóðinn og tilgang hans.

${ }^{13}$ Samkvæmt forstöðumanni sjóðastýringar hjá Kauppingi banka voru sameiningar og lokanir sjóða gerðar sökum hagræðingar. Við sameiningu bankanna runnu tvær eignastýringar saman, við pað tvöfaldaðist framboð sjóða og pví var ákveðið að keyra nokkra peirra saman og breyta heiti á öðrum.

14 Samkvæmt upplýsingum frá VSP er helsta ástæðan fyrir lokun sjóðanna sú að einfalda sjóðaframboð fyrirtækisins.

${ }^{15}$ Með lokuðum sjóðum er hér bæði átt við sjóði sem hefur verið lokað og sameinaðir öðrum. Sameinaðir sjóðir teljast lokaðir ef engin saga flyst með peim.
} 
Tafla 3. Hlutfallslegur árangur sjóða sem var lokað.

Lokaðir sjóðir: Glitnir - Fjármál, Glitnir - Heilsa, Glitnir - Tækni, Kaupping - Einingarbréf 6, VSP - Fjármálasjóðurinn, VSP - Lyf- og líftæknisjóðurinn, VSP - Hátæknisjóðurinn, VSP - Alpjóðasjóðurinn.

Starfandi sjóðir: Glitnir - Global Equity, Glitnir - Fjármál, Glitnir - Heilsa, Glitnir - Heimssafn, Glitnir - Tækni, Kaupping - KMS Emerging Markets, Kaupping - Global Equities, Kaupping - Nordic Growth, Kaupping - KIF Bric, Kaupping KIF Global Equity, Kaupping - KMS Asia Pacific, Kaupping - KMS Europe, Kaupping - KMS Global Styles, Kaupping KMS N-America, Landsbankinn - Global Equity fund, VSP - Alpjóðasjóðurinn, VSP - Fjármálasjóðurinn, VSP Hátæknisjóðurinn, VSP - Lyf- og líftæknisjóðurinn.

\begin{tabular}{|c|c|c|c|}
\hline Tímabil & 2001-2002 & 2003-2004 & 2005-2006 \\
\hline Fjöldi lokaðra sjóða & 1 & 3 & 4 \\
\hline Fjöldi starfandi sjóða & 16 & 15 & 12 \\
\hline $\begin{array}{l}\text { Meðalávöxtun lokaðra sjóða umfram } \\
\text { viðmiðunarvísitölu }\end{array}$ & $-0,10 \%$ & $0,10 \%$ & $-0,04 \%$ \\
\hline $\begin{array}{l}\text { Meðalávöxtun starfandi sjóða umfram } \\
\text { viðmiðunarvísitölu }\end{array}$ & $-0,22 \%$ & $-0,14 \%$ & $0,00 \%$ \\
\hline Mismunur & $0,12 \%$ & $0,24 \%$ & $-0,04 \%$ \\
\hline $\begin{array}{l}\text { Fjöldi lokaðra sjóða með hærri ávöxtun að } \\
\text { frádreginni ávöxtun viðmiðunarvísitölu } \\
\text { samanborið við meðaltal peirra sjóða sem } \\
\text { ekki var lokað }\end{array}$ & 1 & 3 & 2 \\
\hline
\end{tabular}


Tafla 4. Sameining, nafnabreytingar og lokanir verðbréfasjóða.

\begin{tabular}{|c|c|c|c|c|}
\hline & Var & Í dag & Aðgerठ & Dagsetning \\
\hline \multirow[b]{2}{*}{ 寻 } & Sjóður 12 & Heimssafn & Nafnabreyting & \\
\hline & $\begin{array}{l}\text { Fjármál } \\
\text { Heilsa } \\
\text { Lífstíll } \\
\text { Tækni }\end{array}$ & Global Equity & Sameining & \\
\hline \multirow{15}{*}{ } & $\begin{array}{l}\text { Global Equity Class } \\
\text { Global Technology Class }\end{array}$ & Global Growth & Sameining & $\begin{array}{l}\text { jan. } 2004 \\
\text { jan. } 2004\end{array}$ \\
\hline & Global Value Class & Kaupthing Fund Global & Nafnabreyting & \\
\hline & Nordic Growth Class & Kaupthing Fund Nordic & Nafnabreyting & \\
\hline & Einingabréf 6 & & Lokað & jan. 2004 \\
\hline & Alpjóða hlutabréfasjóðurinn & KMS Global Equity & Nafnabreyting & jan. 2004 \\
\hline & $\begin{array}{l}\text { Framsækni Alpjóða } \\
\text { hlutabréfasjóðurinn }\end{array}$ & KMS Global Sector & Innganga & jan. 2004 \\
\hline & KB Erlend Hlutabréf & Kaupthing Erlend & Nafnabreyting & \\
\hline & Global Growth Class & Kaupthing International & Nafnabreyting & jan. 2004 \\
\hline & Nýtæknisjóðurinn & KMS Global Sector & Innganga & nóv. 2003 \\
\hline & $\begin{array}{l}\text { Kaupthing SICAV New } \\
\text { Opportunities }\end{array}$ & KMS Emerging Markets & Nafnabreyting & jan. 2004 \\
\hline & Kaupthing SICAV Intl. Equity & KMS Global Styles & Nafnabreyting & jan. 2004 \\
\hline & Kaupthing SICAV Tech \& Health & & Lokað & jún. 1905 \\
\hline & Kaupthing SICAV Asia & KMS Pacific & Nafnabreyting & jan. 2004 \\
\hline & Kaupthing SICAV Europe & KMS Europe & Nafnabreyting & jan. 2004 \\
\hline & Kaupthing SICAV America & KMS North America & Nafnabreyting & jan. 2004 \\
\hline \multirow{4}{*}{$\bar{s}$} & Alpjóðasjóðurinn & & Lokað & ágú. 2006 \\
\hline & Fjármálasjóðurinn & & Lokað & ágú. 2006 \\
\hline & Hátæknisjóðurinn & & Lokað & ágú. 2006 \\
\hline & Lyf- og tæknisjóðurinn & & Lokað & ágú. 2006 \\
\hline
\end{tabular}


Sama aðferðafræði var notuð pegar skoðaður var hlutfallslegur árangur sjóða sem breyttu um nafn. Skoðaðir voru fimm sjóðir af átta sem breyttu um nafn. ${ }^{16}$ Peir sjóðir sem breyttu um nafn skiluðu lægri ávöxtun heldur en meðaltal peirra sjóða sem breyttu ekki um nafn í premur tilvikum af fimm. Niðurstaðan er pví sú sama og áður, p.e.a.s. að engin afgerandi tengsl eru milli nafnabreytinga og árangurs.

Tafla 5. Hlutfallslegur árangur sjóða sem hafa breytt um nafn.

Sjóðir sem breyttu um nafn: Glitnir - Sjóður 12, Kaupping - Alpjóðahlutabréfasjóðurinn, Kaupping - KIF Bric, Kaupping International Equity, Kaupping - New Opportunities

Sjóðir með óbreytt nafn: Glitnir - Global Equity, Glitnir - Sjóður 12, Kaupping - Global Equities, Kaupping - Global Value, Kaupping - KMS Asia Pacific, Kaupping - KMS Europe, Kaupping - KMS N-America, Kaupping - Nordic Growth, Landsbankinn - Global Equity fund, VSP - Alpjóðasjóðurinn, VSP - Fjármálasjóðurinn, VSP - Hátæknisjóðurinn, VSP — Lyf- og líftæknisjóðurinn.

\begin{tabular}{|c|c|c|}
\hline Tímabil & $2002-2003$ & 2004-2005 \\
\hline Fjöldi sjóða sem breyttu um nafn & 3 & 2 \\
\hline Fjöldi sjóða sem breyttu ekki um nafn & 11 & 8 \\
\hline $\begin{array}{l}\text { Meðalávöxtun umfram viðmiðunarvísitölu } \\
\text { hjá sjóðum sem breyttu um nafn }\end{array}$ & $-0,32 \%$ & $0,16 \%$ \\
\hline $\begin{array}{l}\text { Meðalávöxtun umfram viðmiðunarvísitölu } \\
\text { hjá sjóðum sem breyttu ekki um nafn }\end{array}$ & $-0,20 \%$ & $-0,13 \%$ \\
\hline Mismunur & $-0,12 \%$ & $0,29 \%$ \\
\hline $\begin{array}{l}\text { Fjöldi sjóða sem breyttu um nafn og höfðu hærri } \\
\text { ávöxtun heldur en meðalávöxtun peirra sem } \\
\text { breyttu ekki um nafn }\end{array}$ & 1 & 1 \\
\hline
\end{tabular}

\subsection{Samanburðurá kostnaði}

Bandarískar rannsóknir hafa yfirleitt sýnt fram á neikvætt samband milli árlegs umsýslukostnaðar og ávöxtunar verðbréfasjóða (Sjá t.d. Carhart (1997)). Samkvæmt peirri niðurstöðu eru kostnaðarsamari sjóðir að meðaltali verri heldur en sambærilegir ódýrari sjóðir. Samanburður á kostnaði er samt nokkuð vandasamur par sem fjárfestar greiða oft mismunandi umsýslukostnað eftir umfangi viðskipta og rannsakendur hafa yfirleitt bara aðgang að listaverði. Í okkar tilfelli var notast við listaverð fyrir árið 2006 til að bera saman kostnað íslensku verðbréfasjóðanna við tölur um pá erlendu. Samanburður á kostnaði sjóðanna er gerður á grundvelli hlutdeildarskírteina (e. share class) en erlendir sjóðir gefa gjarnan út tvær til prjár tegundir hlutdeildarskírteina sem bera mismunandi kostnað.

Samanburðurinn var gerður í tvennu lagi. Í fyrsta lagi var borinn saman meðalárs umsýslukostnaður og í öðru lagi meðal inn- og útgöngukostnaður (e. front load, back end load). ${ }^{17}$ Niðurstöður sýna að íslensku sjóðirnir eru með nánast sömu meðaltalspóknun og

\footnotetext{
16 Prír sjóðir Kauppings breyttu um nafn pannig að skammstöfun var sett fyrir framan pað gamla. Petta var talin vera minniháttar breyting og pví eru peir ekki teknir með í matinu. Til dæmis var Kaupping SICAV Europe einungis breytt í KMS Europe.

${ }^{17}$ Á Íslandi er pessi kostnaður skilgreindur sem mismunur á kaup- og sölugengi.
} 
peir erlendu. Mismunurinn er 0,06\% og er tölfræðilega ómarktækur. Íslensku sjóðirnir rukka um 1,52\% í umsýslukostnað að meðaltali á ári en peir erlendu um 1,58\%.

Pegar borinn er saman mismunur á kaup- og sölugengi íslensku sjóðanna við mismun á samanlögðum inn- og útgöngukostnaði erlendu sjóðanna eru íslensku sjóðirnir talsvert ódýrari. Munurinn er nokkuð mikill eða 1,23\%. Pessi munur er hins vegar ekki tölfræðilega marktækur. Íslensku sjóðirnir taka að meðaltali 1,95\% á meðan peir erlendu rukka 3,18\%.18 Pess ber pó að geta að inn- og útgöngukostnaður erlendu sjóðanna er stundum háður skilyrðum sem ekki er hægt að afla upplýsinga um. Til dæmis getur útgöngukostnaður fallið niður eftir tiltekinn tíma ef fjárfestir lætur peninga liggja óhreyfða í sjóðnum.

Niðurstaðan er pví sú að árlegur umsýslukostnaður íslensku sjóðanna samkvæmt listaverði er sambærilegur og hjá peim erlendu en samanlagður inn- og útgöngukostnaður er töluvert lægri að meðaltali hjá peim íslensku.

\section{Lokaorð}

Pessi rannsókn metur samkeppnishæfni íslenskra verðbréfasjóða gagnvart sambærilegum erlendum verðbréfasjóðum. Rannsóknin gefur vísbendingar um að íslensku sjóðirnir skili örlítið hærri ávöxtun að meðaltali en peir erlendu en nokkuð lakari ávöxtun en viðmiðunarvísitala MSCI. Pegar árangur sjóðanna er metinn með tilliti til áhættu kemur hins vegar í ljós að íslensku sjóðirnir skila sambærilegum árangri við pá erlendu.

Heildaráhætta íslensku sjóðanna er aðeins meiri en gengur og gerist meðal peirra erlendu. Heildaráhættan er meiri í 16 af 22 tilvikum og pví vísbending um að íslensku sjóðirnir séu ívið áhættumeiri. Pessi munur sjóðanna liggur aðallega í kerfisbundinni áhættu, en hún er nokkuð meiri hjá peim íslensku. Рað er pó mikilvægt að taka fram að munurinn er aðeins tölfræðilega marktækur í 10 af 22 tilvikum, en í öllum peim tilvikum er kerfisbundin áhætta íslensku sjóðanna meiri. Í mjög fáum tilvikum var afgerandi munur á sértækri áhættu. Mismunurinn á meðalávöxtun skýrist pví af meiri kerfisbundinni áhættu.

Talsvert var um lokanir og breytingar á sjóðum á tímabilinu. Lélegur árangur og lokanir á sjóðum héldust ekki í hendur. Ekki voru heldur sterkar vísbendingar um að nafnabreytingar hafi verið gerðar í kjölfar lélegs árangurs.

Umsýslugjald íslensku og erlendu sjóðanna er mjög ápekkt. Talsverður munur er hins vegar á inn- og útgöngukostnaði sjóðanna. Kostnaður íslensku sjóðanna er um 1,95\% að meðaltali á móti 3,18\% hjá peim erlendu. Mismunur milli sjóðanna er pví tæplega 1,23\%.

Í heild má draga pá ályktun að íslenskir verðbréfasjóðir með alpjóðlega fjárfestingarstefnu séu samkeppnishæfir við sambærilega erlenda sjóði.

${ }^{18}$ Viðauki B inniheldur dreifingu á kostnaðartölum. 


\section{Heimildir}

Barber, B. M., Odean, T. \& Zheng, L. (2005). Out of Sight, Out of Mind: The Effects of Expenses on Mutual Fund Flows. Journal of Finance, 78, 2095-2120.

Brown, S.J. \& Goetzmann, W.N. (1995). Performance Persistence. Journal of Finance, 50, (nr. 2), 679-698.

Carhart, M. (1997), On Peristence in Mutual Fund Performance. Journal of Finance, 52, 57-82.

Cooper, M.J., Gulen, H. \& Rau, P.R. (2005). Changing Names with Style: Mutual Fund Name Changes and Their Effects on Fund Flows. Journal of Finance, 60, (nr. 6), 2825-2858.

Elton, E.J., Gruber, M.J. \& Blake, C.R. (1996). Survivorship Bias and Mutual Fund Performance. The Review of Financial Studies, 9, (nr. 4), 1097-1120.

Glitnir sjóðir hf. (2007). Gögn um ávöxtun og póknun verðbréfasjóða.

Jensen, M. C. (1968). The performance of mutual funds in the period 1945-1966. The Journal of Finance, 23, 389-416.

Kaupping banki. (2007). Gögn um ávöxtun og póknun sjóða. Sótt pann 13. janúar 2007 af veraldarvefnum: http://sjodir.kaupthing.is/template19.asp?PageID=812.

Kaupping banki. (2007). Sameiningar sjóða. Sótt pann 20. janúar 2007 af veraldarvefnum: http://sjodir.kaupthing.is/template21.asp?pageid=1459.

Khorana, A., H. Servaes og P. Tufano (2007). Mutual Fund Fees Around the World. Vinnupappír.

Landsbanki Íslands. (2007). Gögn um ávöxtun og póknun verðbréfasjóða.

Landssamtök lífeyrissjóða. (2007). Sótt pann 25. janúar 2007 af veraldarvefnum:

http://www.ll.is.

Lánstraust hf. (2007). Sótt pann 15. janúar 2007 af veraldarvefnum:

http://sjodir.lt.is/ifx/?MIval=sj_sjodir\&pg=7.

Liang, B. (2001). Hedge Funds Performance 1990-1999. Financial Analysts Journal, 57, (nr. 1), $11-18$.

Lunde, A., Timmermann, A. \& Blake, D. (1999). The hazards of mutual fund underperformance: A Cox regression analysis. Journal of Empirical Finance, 6, 121-152.

Malkiel, B. G. (1995). Returns from Investing in Equity Mutual Funds 1971 to 1991. Journal of Finance, 50, (nr. 2), 549-572.

Morningstar Research Plus. (2006). Morningstar Europe Ltd.. Gögn sótt 15.-31. desember 2006 af veraldarvefnum: http://research.morningstareurope.com/advisor/default.asp

Kári Sigurðsson, Sara Margreta Fuxén og Valgerður Vésteinsdóttir (2006). Hvert er aðalmálið við val á verðbréfasjóđi?. Óbirt B.Sc.-ritgerð: Háskólinn í Reykjavík, Viðskiptadeild.

Seðlabanki Íslands. (2007). Gögn um eignaskiptingu íslenskra verðbréfasjóða.

Sharpe, W. (1964). Capital asset prices: A theory of market equilibrium under conditions of risk. Journal of Finance, 19, (nr. 3), 425-442. 
Sharpe, W. (1966). Mutual Fund Performance. Journal of Business, 39, (nr. 1), 119-138.

Sparisjóðirnir (VSP). (2007). Gögn um ávöxtun og póknun verðbréfasjóða. Sótt pann 13. janúar 2007 af veraldarvefnum: http://www.spar.is/categoryplain.aspx?catID=38

Wermers, R. (2000). Mutual Fund Performance: An Empirical Decomposition into StockPicking Talent, Style, Transactions Costs, and Expenses. Journal of Finance, 55, (nr. 4), 16551695. 


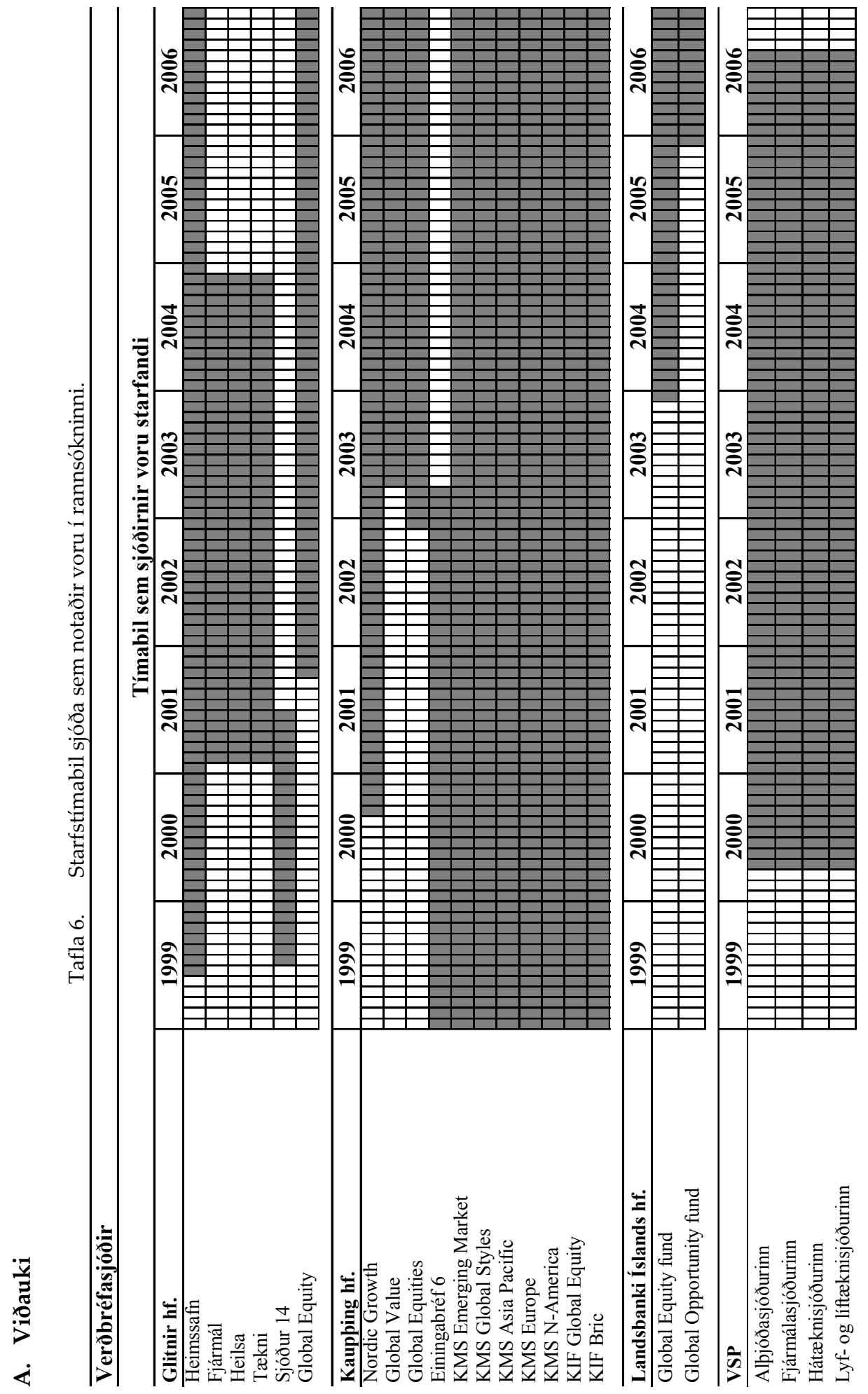




\section{B. Viðauki}

Mynd 4. Dreifing á umsýslupóknun erlendra verðbréfasjóða sem tilheyra samanburðarmengi (\% á ári).

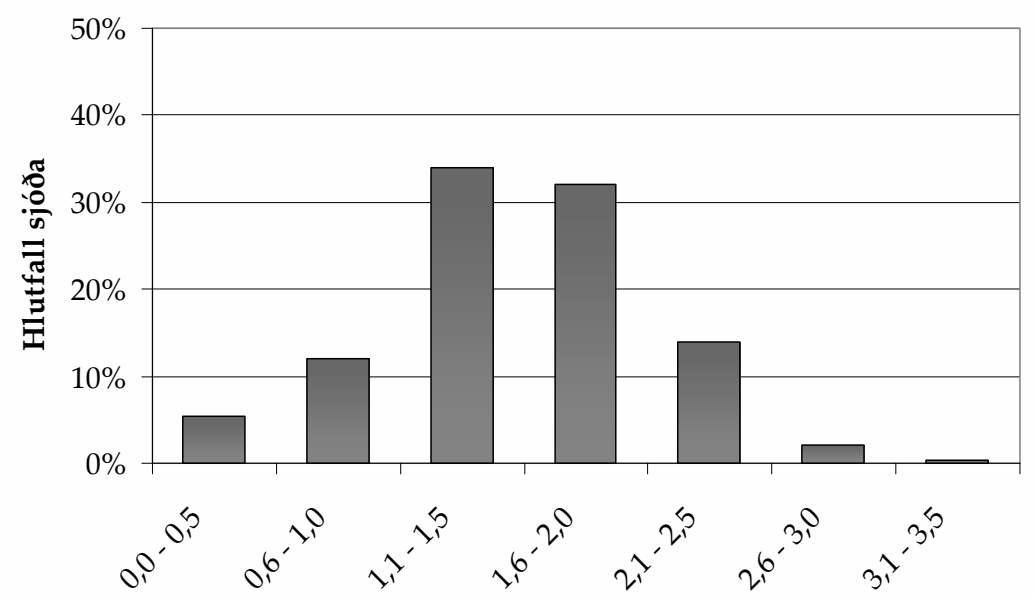

Mynd 5. Dreifing á samanlögðum inn- og útgöngukostnaði erlendra verðbréfasjóða sem tilheyra samanburðarmengi (\%).

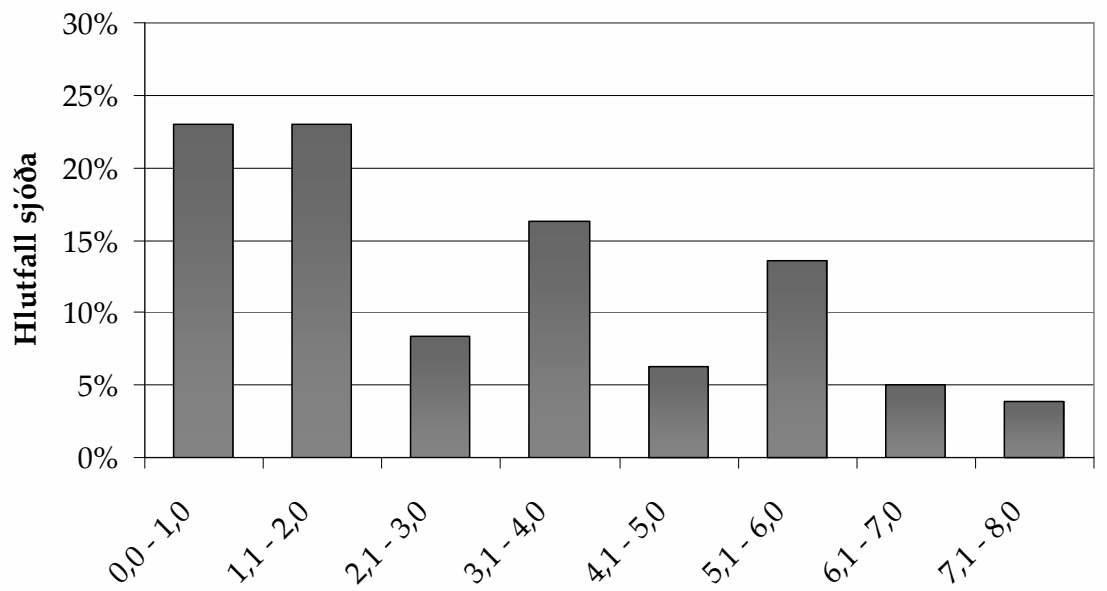

